\title{
Upaya Meningkatkan Hasil Belajar IPA Melalui Model Pembelajaran Kooperatif Tipe Umpan Balik pada Siswa Kelas IV B SD Negeri 64/IV Kota Jambi
}

\author{
Susirah \\ Guru SD Negeri 64/IV Kota Jambi \\ Email: susirahjambi@yahoo.com
}

\begin{abstract}
The background of this research is that science learning in general at the elementary school level is mostly carried out with the lecture method, teachers are reluctant to use learning media or teaching aids, on the grounds that the use of teaching aids or learning media requires a large amount of money and is not practical. Without realizing it, that is what causes the students' learning activeness and results of science to be low. The purpose of this action research is to know the improvement of science learning outcomes after the use of the feedback type cooperative learning model in class IV B 64 / IV Jambi Elementary School students. The subjects in this study amounted to 30 students. This study uses classroom action research conducted in two rounds. Each round consists of four stages, namely: design, activity and observation, reflection, and revision. Data obtained in the form of formative test results, observation sheets of teaching and learning activities. From the results of data analysts, it was found that student learning outcomes experienced a significant increase. the increase in learning outcomes was marked by an increase in student learning completeness in each cycle, namely the pre cycle (59.50\%), the first cycle (68.33\%) and the second cycle (80.75\%). From the results of the data analysis it can be concluded that the Cooperative Cooperative Type Feedback type learning model can positively influence the increase in activity and learning outcomes of class IV B students of 64 / IV Jambi City Elementary School, and this learning model can be used as an alternative in science learning next.
\end{abstract}

Keywords: Feedback type Cooperative Learning Model, Science

\section{PENDAHULUAN}

Sumber daya manusia yang profesional dapat diperoleh melalui berbagai pengembangan secara menyeluruh. Potensi sumber daya manusia pada hakikatnya adalah salah satu modal dasar pembangunan nasional. Namun selama ini masih dirasakan bahwa potensi sumber daya manusia tersebut belum dapat dimanfaatkan secara optimal mengingat sebagian besar dari angkatan kerja, tingkat keterampilan dan pendidikannya masih rendah. Rendahnya pendidikan akan sangat berpengaruh besar terhadap sikap mental tenaga kerja yang berakibat rendahnya unjuk kerja Untuk mendapatkan manusia-manusia potensial dibutuhkan kelembagaan pendidikan yang tangguh, yaitu yang dapat memberikan bekal kepada siswa dalam mengembangkan kehidupan sebagai pribadi, anggota masyarakat, warga negara dan mempersiapkan siswa untuk mengikuti pendidikan selanjutnya.

Adanya keinginan untuk meningkatkan kualitas diri sesuai nilai dan norma yang berlaku di lingkungan, diperlukan peningkatan pendidikan. Untuk memenuhi kebutuhan itu, terjadi perubahan kurikulum yang disesuaikan dengan perkembangan dan kemajuan jaman yang telah dipertimbangkan dalam kebijakan. Kebijakan nasional yang berlaku. Implementasi kebijakan tersebut Kurikulum Tingkat Satuan Pendidikan (KTSP) yang berisi tentang seperangkat rencana dan pengaturan tentang kompetensi yang dibakukan untuk mencapai tujuan nasional dan cara penerapannya disesuaikan dengan keadaan dan kemampuan daerah, serta Sekolah/Madrasah. Adapun yang dimaksud dengan kompetensi adalah "Pengetahuan, keterampilan dan nilai-nilai dasar yang direfleksikan dalam kebiasaan berfikir dan bertindak, dalam arti memiliki pengetahuan keterampilan dan nilai-nilai dasar untuk melakukan sesuatu" (Depdiknas 2006:2).

Sesuai dengan zamannya, guru yang bermutu harus mempunyai kemampuan profesional. Dalam hal ini Proyek Pengembangan Pendidikan Guru (1979) merumuskan tiga kemapuan penting yang harus dimiliki oleh seorang guru yang profesional yaitu (1) kompetensi profesional, (2) kompetensi personal, dan (3) kompetensi sosial (Arikunto, 1990:238-239). Guru merupakan kunci dalam meningkatkan mutu pendidikan dan mereka berada di titik sentral dari setiap usaha reformasi pendidikan yang diarahkan pada perubahanperubahan kualitatif. Berbagai usaha dilakukan dalam peningkatan mutu pendidikan tidak akan menunjukkan hasil yang berarti apabila tetap mengesampingkan guru. Guru dengan keterlibatannya dalam pembaharuan kurikulum, pengembangan metode-metode mengajar, penyediaan sarana dan prasarana akan mengubah wajah pendidikan itu sendiri.

Diantaranya pendidikan yang diajarkan di sekolah dasar adalah mata pelajaran IImu Pengetahuan Alam. Berdasarkan hasil tes formatif siswa pada pembelajaran IPA siswa kelas IV B SD Negeri 64/IV Kota Jambi menunjukkan bahwa hasil pembelajaran IPA dengan materi Mahluk hiupdan Lingkungannya masih rendah itu terlihat dari nilai rata-rata siswa 5,50.

Suatu kenyataan bahwa pembelajaran IPA yang dialami selama ini masih jauh dari yang diharapkan, yaitu dilaksanakan guru dengan lebih menekankan pada metode ceramah yang tidak kreatif. Sering dilaksanakan dalam suatu kegiatan pembelajaran, sehingga aktivitas pembelajaran selalu didominasikan oleh guru. Siswa menjadi pelajaran yang pasif, dan cepat merasa bosan dalam belajar. Hal ini dikarenakan pula langkahnya penggunaan/pemanfaatan alat-alat penunjang pembelajaran. Siswa hanya hanya menjadi pendengar, penulis ringkasan atau pencatat materi yang ada pada buku sumber.

Penggunaan metode umpan balik merupakan solusi dari masalah yang ada pada penelitian, sebagai upaya meningkatkan hasil belajar siswa pada mata pelajaran IPA kelas IV B. Umpan balik merupakan sebuah proses di kelas yang telah menjadi daya tarik 
tersendiri bagi para peneliti praktik pembelajaran sejak tahun 1970-an hingga sekarang ini. Secara konsisten, para peneliti telah menemukan bukti-bukti bahwa ketika guru mampu menggunakan prosedur umpan balik yang efektif ternyata dapat meningkatkan prestasi belajar siswanya.

Setiap anak didik mempunyai motivasi belajar yang berlainan. Oleh karena itu, setiap guru dituntut unutk memahami hal ini agar pengajaran yang dilakukan tidak asal-asalan. Guru yang mengabaikan perbedaan motivasi dalam diri anak setiap anak didik cenderung mengalami kegagalan dalam melaksankan tugasnya mengajar di kelas (Syaiful Bahri D dan Aswan Zain, 2006:142).

Dengan umpan balik dimaksudkan bahwa guru dan siswa menciptakan suasana pembelajaran yang aktif, kreatif dan menyenangkan. Guru dapat merangsang siswa agar lebih aktif dalam pembelajaran. Umpan balik yang efektif merupakan bagian integral dari sebuah dialog instruksional antara guru dengan siswa, siswa dengan siswa, maupun siswa dengan dirinya sendiri, dan bukanlah sebuah praktik yang terpisahkan (Akhmad Sudrajat, 2009)

\section{Kajian Teori \\ Proses Pengajaran}

Proses belajar merupakan bentuk prilaku manusia yang sangat penting dan utama bagi kelangsungan hidup manusia. Proses belajar membantu manusia menyesuaikan diri dengan lingkungan di sekitarnya agar ia dapat mempertahankan kelangsungan hidupnya. Banyak pengertian belajar yang dikemukakan oleh para ahli, salah satunya menurut Gagne (1984), bahwa belajar adalah suatu proses di mana suatu organisme berubah prilakunya sebagai akibat pengalaman ( Strategi Belajar Mengajar, 2004:2.3), Juga menurut Gagne (1984) belajar dapat didefinisikan sebagai suatu proses di mana suatu organisme berubah akibat pengalaman.

Dengan menjalani proses, akan terjadi perubahan dalam diri seseorang, apabila sebelum menjalani proses belajar seseorang belum mempunyai pengetahuan akan sesuatu hal dan belum mepunyai keterampilan tertentu dan bersikap tidak menolak pada infomasi yang diberikan, maka setelah menjalani proses belajar la akan menjadi tahu atau lebih tahu, dan menjadi trampil atau lebih trampil. Proses perubahan yang terjadi harus relative bersifat menetapkan tidak terjadi hanya pada saat ini Nampak, tetapi juga pada perilaku yang mungkin terjadi pada masa mendatang

Berdasarkan uraian di atas, maka proses pengajaran dimaknai sebagai suatu proses terencana dan memiliki tujuan tertentu, baik yang ditetapkan oleh siswa maupun oleh pengajar, sehingga individu yang terlibat dalam proses tersebut akan mengalami perubahan sebagaimana yang diharapkan. Dari artian ini proses pengajaran merupakan proses yang dengan sengaja dirancang sedemikian rupa sesuai dengan tujuan yang telah ditetapkan untuk dapat mengubah perilaku siswa.

Dalam proses belajar mengajar pada mata pelajaran IPA, guru hendaknya menyampaikan atau mengalihkan pesan atau pengetahuan yang diyakini berguna bagi siswa dikemudian hari untuk dipelajari dan dipahami. Selain itu, dalam proses belajar mengajar, guru juga menyampaikan cara efektif yang dapat dilakukan siswa untuk dapat memahami atau mempelajari materi yang disampaikan, serta memberikan umpan balik mengenai perkembangan proses belajar yang dijalani siswa. Dari sisi siswa juga diharapkan agar mereka dapat menyampaikan informasi kepada guru bahwa materi yang disampaikan guru , tidak atau belum dapat difahami atau dimengerti, sehingga dapat dilakukan pengulangan proses belajar.

Keberhasilan proses pembelajaran tidak terlepas dari cara pendidik mengajar dan peserta didik belajar, sebab baik tidaknya proses pembelajaran dapat dilihat dan dirasakan oleh pendidik dan peserta didik sendiri. Proses belajar mengajar dikatakan berhasil apabila ada perubahan pada diri peserta didik, menyangkut pengetahuan sikap dan keterampilan, dan juga didalam proses pembelajaran peserta didik harus menunjukan kegairahan belajar yang tinggi, semangat kerja yang besar dan percaya pada diri sendiri (Ade Rukmana dan Asep Suryana, 2006: 13).

Sebagai orang yang menginginkan keberhasilan dalam mengajar, guru selalu mempertahankan agar umpan balik selalu berlangsung dalam diri anak. Umpan balik itu tidak hanya dalam bentuk fisik tetapi juga dalam bentuk mental yang selalu berproses untuk menyerap bahan pelajaran yang diberikan guru. Untuk mendapatkan umpan balik dari anak didik diperlukan beberapa teknik yang sesuai dan tepat dengan diri anak didik sebagai makhluk individual. Berikut ini beberapa teknik untuk mendapatkan umpan balik dair anak didik (Syaiful Bahri D dan Aswan Zain, 2006:143) :

a. Memancing Apersepsi Anak

b. Memanfaatkan Taktik Alat Bantu yang Akseptabel

c. Memilih Bentuk Motivasi yang Akurat

d. Menggunakan Metode yang Bervariasi

Berdasarkan analisis teori-teori di atas, dalam memperbaiki hasil belajar siswa terutama mata pelajaran IPA, penelitian ini difokuskan untuk meningkatkan hasil belajar siswa dengan menggunakan metode umpan balik.

Untuk mengetahui berhasil tidaknya seorang guru dalam menyampaikan materi pembelajaran bisa dilihat dari hasil kerja siswa. Untuk itu guru harus mengadakan penilaian, dengan mengadakan penilaian, guru dapat melihat sejauh mana kemampuan siswa dalam menyerap materi pembelajaran. Hopkins dan Stanley (1981) menyatakan bahwa "Ada kelompok pelaku pendidikan yang harus memperhatikan hasil penilaian. Kelompok tersebut adalah (guru, anak didik dan orang tua murid)"

Dalam melaksanakan penilaian, ada beberapa cara, misalnya dengan tes lisan atau tes tertulis. Tes lisan bisa berupa tanya jawab langsung dengan siswa, sedangkan tes tulis ada uraian, essay dan pilihan ganda. Guru bisa mengambil satu diantara cara penilaian tersebut, bisa juga digunakan semua seperti ulangan semester.

\section{Hasil Belajar}

Hasil belajar adalah hasil yang dicapai oleh siswa setelah mengikuti serangkaian kegiatan intruksional tertentu. Hasil belajar yang dicapai oleh siswa 
berhubngan erat dengan rumusan intruksional yang direncanakan oleh guru sebelumnya. Hasil dan bukti belajar adalah adanyan perubahan tingkah lakuorang yang belajar yang terjadi karena proses pematangan dan hasil belajar bersifat relatif menetap,misalnya dari tidak tahumenjadi tahu dan dari tidak mengerti menjadi mengerti. Menurut Mudjiono, bahwa hasil dan bukti belajar adalah perubahan tingkah laku orang yang belajar. Nilai merupakan hasil dari proses penilaian. Nilai merupakan hasil dari proses penilaian. Nilai diperoleh dengan mengubah skor dengan skala dan acuan tertentu. Oleh karena itu, nilai hanya dapat dimaknai dan digunakan sebagai pengambilan keputusan dengan memperhatikan skala dan acuan yang digunakan. 4 Menurut Howard Kingsley (Sudjana), ada tiga macam hasil belajar yakni :

1. Keterampilan dan kebiasaan

2. Pengetahuan dan pengertian

3. Sikap dan cita-cita Masing-masing golongan dapat diisi dengan bahan yang diterapkan dalam kurikulum sekolah.

Benyamin Bloom berpendapat bahwa tujuan pendidikan yang dalam hendak kita capai terdiri dari tiga bidang, yaitu bidang kognitif, bidang afektif dan bidang psikomotorik. Setiap kegiatan yang berlangsung pada akhirnya kita ingin mengetahui hasilnya, demikian juga dengan pembelajaran, untuk mengetahui hasil kegiatan pembelajaran, harus dilakukan pengukuran dan penilaian. Pengukuran adalah suatu usaha untuk mengetahui keberhasilan belajar dalam penguasaan kompetensi.

Dengan demikian pengukuran hasil belajar adalah suatu usaha untuk mengetahui status kompetensi dengan menggunakan alat ukur sesuai dengan apa yang diukur, sedangkan penialian adalah usaha untuk membandingkanhasil pengukuran dengan patokan yang ditetapkan. Jadi, hasil belajar adalah hasil yang telah dicapai dari suatu kegiatan yang elah dikerjakan, diciptakan dan menyenangkan hati yang diperoleh dengan jalan keuletan, baik secara individu maupun secara kelompok dalam kegiatan tertentu.

\section{Pengertian Metode Umpan Balik}

Pengertiam Metode Umpan Balik adalah pemberian informasi yang diperoleh dari tes atau alat ukur lainnya kepada siswa untuk memperbaiki atau meningkatkan pencapaian atau hasil belajar Siswa menerima umpan balik dari guru dalam bentuk lisan maupun tulisan. Umpan balik verbal umumnya diberikan pada sesi tanya jawab. Sedangkan salah satu umpan balik tertulis yang paling umum diberikan adalah nilainilai dalam penilaian formal, seperti ujian tertulis dengan menggunakan kertas dan pensil.

Siswa memiliki hak untuk memahami situasi pembelajaran mereka, sarana- sarana yang diharapkan dapat mereka penuhi, dan pada level berapa mereka harus menunjukkan kesuksesannya. Umpan balik yang berkaitan dengan performa (perform) dan pencapaian (achievement) harus diberikan secara berkelanjutan, dan siswa harus mengetahui bagaimana mereka menunjukkan performanya setiap wakltu. Suatu realita sehari-hari didalam suatu ruang kelas ketika sesi kegiatan belajar mengajar berlangsung, nampak beberapa atau sebagian siswa belum mampu mencapai kompetensi individu yang diperlukan untuk mengikuti pelajaran lanjutan. Juga, beberapa siswa belum belajar sampai pada tingkat pemahaman.

Siswa baru mampu mempelajari (baca:menghafal) fakta, konsep, prinsip, hukum, teori dan gagasan inovatif lainnya pada tingkat ingatan,mereka bosan inovatif lainnya pada tingkat ingatan,mereka belum dapat menggunakan dan menerapkannya secara efektif dalam pemecahan masalah sehari-hari yang konstektual. Ini terjadi karena guru belum optimal memperdayakan ' tambang emas potensi masing-masing siswa yang seringkali tersembuny. Bila dibuat ilustrasi tentang siswa, kegiatan belajar mengajar (KBM), lulusan, kurikulum, dan lingkungan dalam sistem.

Pada permasalahan ini adalah salah satu metode yang mendukung yaitu Metode Umpan balik yang akan penulis bahas, bagaimana tehnik-tehnik mendapatkan umpan balik, diantaranya dengan memancing apersepsi anak didik, memanfaatkan tehnik alat bantu akseptabel, dan menggunakan metode yang berfariasi.

\section{Keuntungan dan kerugian Metode Umpan Balik}

1. Metode ini dapat mempelajari situasi yang nyata

2. Dapat membuat peserta didik belajar dari umpan balik yang datang dari dirinya sendiri

3. Dapat melatih peserta didik dalam mensumulasikansesuatu sehingga peserta didik menjadi lebih berani

4. Peserta didik dapat lebih menggunakan sekumpulan fakta dan konsep

\section{Kerugian metode umpan balik}

1. Bagi peserta didik yang penakut penerapan metode ini menjadi hal yang tidak menyenangkan sehingga enggan untuk bersimulasi

2. Sebaliknya bagi pesereta didik yang pandai yang senang berbicara cendrung menguasai proses umpan balik

3. Bagi peserta didik yang susah mengeluarkan pendapat hal ini merupakan metode yang paling menyusahkan.

\section{Fungsi umpan balik}

1. Fungsi informasional yaitu memberikan informasi sejauh mana siswa telah menguasai materi yang diterimanya dalam proses atau kebijakan belajar mengajar

2. Fungsi motifasional yaitu motifasi siswa untuk belajar

3. Fungsi komunikasional umpan balik berfungsi sebagai media penyampaian hasil evaluasi kepada siswadan bersama siswa memberiken upayaperbaikan dan peningkatan.

\section{METODE PENELITIAN \\ Jenis Penelitian}

Penelitian ini merupakan penelitian tindakan kelas, karena penelitian dilakukan untuk memecahkan masalah pembelajaran siswa kelas IV B SD Negeri 64/IV Kota Jambi. Penelitian ini juga termasuk penelitian deskriptif, sebab menggambarkan bagaimana suatu teknik pembelajaran pembelajaran diterapkan dan bagaimana hasil yang diinginkan dapat tercapai. Menurut sukidin dkk. (2002:54) ada 4 macam bentuk penelitiaan tindakan, yaitu :

(1) Penelitian tindakan guru sebagai peneliti, 
(2) penelitian tindakan kolaboratif,

(3) penelitian tindakan simultan terintegratif, dan

(4) penelitian tindakan sosial eksperimental.

Dengan demikian jenis penelitian yang digunakan peneliti adalah dalam bentuk PTK yang dilaksanakan sebanyak 2 Siklus yang teridiri dari siklus I ( $2 \mathrm{x}$ pertemuan ) dan siklus II ( $2 x$ pertemuan). Apabila hasil pada siklus I belum mencapai keberhasilannya maka dilanjutkan pada siklus II. Sedangkan bentuk tindakan yang dilakukan adalah guru sebagai peneliti dibantu oleh seorang observer sebagai penelitian tindakan kolaboratifnya. Penelitian ini mengacu pada perbaikan pembelajaran yang berkesinambungan. Kemmis dan Taggart (1988:14) menyatakan bahwa model penelitian tindakan adalah berbentuk 4 tahapan.Tahapan penelitian tindakan pada suatu siklus meliputi perencanaan atau pelaksanaan observasi dan refleks

\section{Lokasi dan Waktu Penelitian Lokasi Penelitian}

Penelitian ini dilakukan di SD Negeri 64/IV Kota Jambi. Alasan dipilihnya lokasi ini, karena peneliti merupakan salah satu guru di sekolah tersebut mengajar mata pelajaran IImu Pengetahuan Alam yang mengajar siswa kelas IV B Pada semester ganjil tahun ajaran 2018/2019.

\section{Waktu Penelitian}

Waktu penelitian ini dilaksanakan pada bulan Agustus sampai Oktober semester ganjil tahun pelajaran 2018/2019. Materi yang disampaikan adalah "Makhluk hidup dan lingkungannya ".

\section{Subjek Penelitian}

Adapun yang menjadi subjek dalam penelitian ini adalah siswa kelas IV B SD Negeri 64/IV Kota Jambi dengan jumlah 30 peserta didik yang terdiri 18 laki-laki dan 12 perempuan. Pada kegiatan penelitian ini peneliti dibantu oleh teman sejawat sebagai informan dalam pelaksanaan penelitian mata pelajaran IImu Pengetahuan Alam dengan materi Makhluk hidup dan lingkungannya.

\section{Jenis Pengumpulan Data}

Jenis data yang didapat adalah kualitatif dan kuantitatif yang terdiri dari: rencana pembelajaran, hasil observasi dan sumber data. Data ini bersumber dari siswa kelas IV B SD Negeri 64/IV Kota Jambi yang berjumlah 30 orang.

\section{Teknik Pengumpulan Data}

Adapun tehnik pengumpulan data yang digunakan dalam penelitiaan ini adalah sebagai berikut :

a. Observasi. Peneliti mengamati dan mencatat secara sistematis terhadap gejala- gejala pada objek penelitian, dengan memperhatikan respon murid sebelun dan sesudah pembelajaran dengan mnenggunakan metode umpan balik didalam kelas. Dengan menggunakan lembar observasi yang telah peneliti siapkan, penelitian diberikan disertai dengan pembobotan pada setiap indicator motivasi. Di samping itu observasi yang dilakaukan observer untuk mengamati penelitian dalam pengelolaan pembelajaran di kelas.
Tabel 1. Klasifikasi Persentase Pengelolaan Pembelajaran Guru

\begin{tabular}{ccc}
\hline No & Persentase & Kategori Kinerja Guru \\
\hline 1 & $86-100 \%$ & Sangat baik \\
2 & $71 \%-85 \%$ & Baik \\
3 & $56 \%-70 \%$ & Cukup \\
4 & 55 kebawah & Kurang \\
\hline
\end{tabular}

b. Dokumentasi Dokumentasi digunakan untuk mengetahui nama-nama murid, nilai siswa, dan latar belakang siswa serta buku-buku yang relevan digunakan dalam menunjang penelitian ini.

c. Wawancara Peneliti melakukan wawancara terhadap guru bidang studi IPA kelas IV A SD Negeri 64/IV Kota Jambi untuk mengetahui tingkat kemampuan siswa dalam mengatasi masalah penggunaan metode umpan balik pada siswa.

d. Tes formatif untuk mengukur hasil belajar siswa dilakukan secara tertulis

Tabel 2. Klasifikasi Persentase Hasil Belajar Siswa

\begin{tabular}{ccc}
\hline No & Persentase & Kategori Hasil Nilai Belajar \\
\hline 1 & $90 \%-100 \%$ & Sangat Baik \\
2 & $79-89 \%$ & Baik \\
3 & $68 \%-78 \%$ & Cukup \\
4 & $59 \%-69 \%$ & Kurang \\
5 & $57 \%$ kebawah & Sangat Kurang \\
\hline
\end{tabular}

\section{HASIL DAN PEMBAHASAN}

\section{Gambaran Umum Lokasi Penelitian}

Gambaran umum lokasi penelitian tindakan kelas ini adalah di SD Negeri 64/IV Kota Jambi. Alamat sekolah tersebut terletak di Jalan Ir.H. Juanda Kartawijaya Kel. Mayang Mangurai Kec. Kota Baru Jambi. Adapun akreditasi sekolah adalah A yang didirikan pada tahun 1977 dan beroperasi pada tahun 1977 dengan luas tanah 2.063M dengan luas bangunan 2.063M.. Status bangunan merupakan milik Pemda Kota Jambi.

Rombongan belajar SD Negeri 64/IV Kota Jambi sebanyak 16 Kelas, 1 ruang kepala sekolah, dan 1 ruang perpustakaan, 1 ruang Majelis guru, 1 ruang koperasi, 1 ruang UKS. WC, Kantin dan Musholah I buah. Jumlah guru PNS 25 orang, 12 orang guru honor sekolah. Berdasarkan dari data jumlah guru yang PNS saja menunjukkan bahwa sekolah tersebut jumlah guru dan ruang kelasnya sudah menunjukkan sekolah besar.

\section{Gambaran Umum Subjek Penelitian}

Gambaran umum subjek penelitan ini adalah siswa kelas IV B SD Negeri 64/IV Kota Jambi. Sebelum dilakukan penelitian tindakan perbaikan, di awal peneliti sebagai guru mengajar mata pelajaran IPA dengan tema "Makhluk hidup dan lingkungannya" siswa Kelas IV B dalam melaksanakan pembelajaran masih sangat konvensial, belum menggunakan metode, teknik, dan strategi yang tepat untuk pencapaian indikator dan kompetensi dasar pembelajaran. Pada kondisi ini terlihat para peserta didik kurang bersemangat dalam belajar, sehingga masih terlihat peserta didik yang tidak memperhatikan ketika guru menerangkan di depan kelas dengan mengobrol dengan sesama peserta didik lainnya. Hal ini berdampak pada hasil belajar peserta didik yang rendah, yang dapat di lihat pada tabel di bawah ini: 
Tabel 3. Nilai Tes Formatif Pada Pra Siklus

\begin{tabular}{|c|c|c|}
\hline $\begin{array}{c}\text { No. } \\
\text { Urut }\end{array}$ & Nilai & Keterangan \\
\hline \hline 1 & 60 & Tidak Tuntas \\
\hline 2 & 70 & Tidak Tuntas \\
\hline 3 & 75 & Tuntas \\
\hline 4 & 70 & Tidak Tuntas \\
\hline 5 & 55 & Tidak Tuntas \\
\hline 6 & 80 & Tuntas \\
\hline 7 & 75 & Tuntas \\
\hline 8 & 75 & Tuntas \\
\hline 9 & 50 & Tidak Tuntas \\
\hline 10 & 60 & Tidak Tuntas \\
\hline 11 & 50 & Tidak Tuntas \\
\hline 12 & 75 & Tuntas \\
\hline 13 & 75 & Tuntas \\
\hline 14 & 60 & Tidak tuntas \\
\hline 15 & 50 & Tidak Tuntas \\
\hline
\end{tabular}

\begin{tabular}{|c|c|c|}
\hline $\begin{array}{c}\text { No. } \\
\text { Urut }\end{array}$ & Nilai & Keterangan \\
\hline \hline 16 & 40 & Tidak Tuntas \\
\hline 17 & 75 & Tuntas \\
\hline 18 & 50 & Tidak Tuntas \\
\hline 19 & 75 & Tuntas \\
\hline 20 & 75 & Tuntas \\
\hline 21 & 75 & Tuntas \\
\hline 22 & 70 & Tidak Tuntas \\
\hline 23 & 60 & Tuntas \\
\hline 24 & 75 & Tidak Tuntas \\
\hline 25 & 50 & Tidak Tuntas \\
\hline 26 & 50 & Tidak Tuntas \\
\hline 27 & 40 & Tuntas \\
\hline 28 & 60 & Tidak Tuntas \\
\hline 29 & 60 & Tidak Tuntas \\
\hline 30 & 55 & \\
\hline
\end{tabular}

\begin{tabular}{rl|}
\hline Jumlah Nilai $=$ & 1890 \\
Jumlah Nilai Maksimal Ideal $=$ & 3000 \\
Rata-Rata Nilai Tercapai $=$ & 63 \\
\hline
\end{tabular}

Tabel 4. Rekapitulasi Hasil Tes Formatif Pada Pra Siklus

\begin{tabular}{|c|l|c|}
\hline No. & \multicolumn{1}{|c|}{ Uraian } & \multicolumn{1}{|c|}{ Hasil Pra Siklus } \\
\hline \hline 1. & Nilai rata-rata tes formatif & 63 \\
\hline 2. & Jumlah peserta didik yang tuntas belajar & 12 \\
\hline 3. & Persentase ketuntasan belajar & 40 \\
\hline
\end{tabular}

Dari tabel di atas dapat dijelaskan bahwa sebelum menerapkan model pembelajaran unpan balik diperoleh nilai rata-rata hasil belajar peserta didik adalah 63 dan ketuntasan belajar mencapai $40 \%$ atau ada 12 peserta didik dari 30 peserta didik sudah tuntas belajar. Hasil tersebut menunjukkan bahwa pada pra siklus secara klasikal peserta didik belum tuntas belajar. Untuk itu peneliti dengan dibantu teman sejawat berupaya melakukan tindakan perbaikan guna meningkatkan hasil belajar siswa dengan mencari metode pembelajaran yang dianggap tepat. Berdasarkan hasil diskusi kecil dengan teman sejawat maka ditentukanlah metode pembelajaran dengan menggunakan metode unpan balik yang akan digunakan dalam proses tindakan perbaikan pembelajaran IPA dengan materi makhluk hidup dan lingkungannya di Kelas IV B yang diharapkan dapat meningkatkan hasil belajar IPA yang pelaksanaannya akan dilaksanakan dalam 2 siklus untuk 2 kali pertemuan setiap siklus.
Berdasarkan kenyataan-kenyataan di atas, peneliti dibantu oleh teman sejawat melakukan kajian dan telah yang akan dipergunakan sebagai dasar pertimbangan memilih strategi pembelajaran yang tepat, dalam upaya melakukan tindakan perbaikan pada pembelajaran IPA. Setelah berdiskusi dan mempertimbangkan berbagai alasan tersebut, peneliti memilih model pembelajaran koooperatif tipe think pair share. Model ini akan dipergunakan dalam PTK yang akan dilaksanakan pada saat berlangsungnya proses pembelajaran dikelas IV B SD Negeri 64/IV Kota Jambi dengan tema" Makhluk hidup dan lingkungannya siswa Kelas IV B". Seluruh rangkaian PTK tersebut selanjutnya dibagi menjadi beberapa tahapan, yang sering disebut dengan siklus.Penerapan siklus merupakan bagian dari tahapan sebuah PTK yang bertujuan untuk mendapatkan data penelitian.

\section{Siklus I}

Hasil Tes Peserta Didik

Tabel 5. Hasil Tes Formatif Peserta Didik Siklus I

\begin{tabular}{clcccc}
\hline No. & Nama & Nilai UH 1 & Nilai UH 2 & Rata-Rata & Kriteria \\
\hline 1 & Adelio Noor Alvaro & 80 & 80 & 80 & Tuntas \\
2 & Ananda Saputra & 60 & 70 & 65 & Tidak Tuntas \\
3 & Cherlly Ayu Cantika Putri & 80 & 80 & 80 & Tuntas \\
4 & Dafa Aprilliandy & 70 & 70 & 70 & Tuntas \\
5 & Deby Chintya Bella & 80 & 80 & 80 & Tuntas \\
6 & Dzakiyah Rafifah Artanti & 70 & 70 & 70 & Tuntas \\
7 & Gania Aura Darningsih & 50 & 50 & 50 & Tidak Tuntas \\
8 & Gavrila Pratama Ivander S & 70 & 70 & 70 & Tuntas \\
9 & Gita Amelia Putri & 50 & 50 & 50 & Tidak Tuntas \\
10 & Iqbal Mediawan & 70 & 70 & 70 & Tuntas \\
11 & Julius Manulang & 60 & 60 & 60 & Tidak Tuntas \\
12 & Kalila Azzahra Putri Nasution & 50 & 50 & 50 & Tidak Tuntas
\end{tabular}




\begin{tabular}{|c|c|c|c|c|c|}
\hline 13 & Muhammad Fadhil Rizqi & 70 & 70 & 70 & Tuntas \\
\hline 14 & Meyza Syarif & 60 & 60 & 60 & Tidak Tuntas \\
\hline 15 & Aupa Dzakia Fahmi & 80 & 80 & 80 & Tuntas \\
\hline 16 & Muhammad Fikri Alfalah & 80 & 80 & 80 & Tuntas \\
\hline 17 & Muhammad Haikal & 80 & 80 & 80 & Tuntas \\
\hline 18 & Muhammad Novriyansyah & 80 & 80 & 80 & Tuntas \\
\hline 19 & Muhammad Revan Ferdinansya & 80 & 80 & 80 & Tuntas \\
\hline 20 & Nadia Balqis Adila & 80 & 80 & 80 & Tuntas \\
\hline 21 & Narendra Gayuh Rajasa & 60 & 60 & 60 & Tidak Tuntas \\
\hline 22 & Natasia Novianti Siahaan & 80 & 80 & 80 & Tuntas \\
\hline 23 & Nazila Winastia & 70 & 70 & 70 & Tuntas \\
\hline 24 & Oktafianus Viter Samosir & 60 & 60 & 60 & Tidak Tuntas \\
\hline 25 & Quinsha Nabila Vadisha & 60 & 60 & 60 & Tidak Tuntas \\
\hline 26 & Ramot Samuel Mangapoi Hutas & 60 & 60 & 60 & Tidak Tuntas \\
\hline 27 & Rivaldo & 70 & 70 & 70 & Tuntas \\
\hline 28 & Rizki Naufal Nadhif & 70 & 70 & 70 & Tuntas \\
\hline 29 & Rohana Enjelika Rumabutar & 60 & 60 & 60 & Tidak Tuntas \\
\hline 30 & Rosa Paulina & 50 & 60 & 55 & Tidak Tuntas \\
\hline & Jumlah & 2040 & 2060 & 2050 & \\
\hline & rata-rata nilai UH 1 dan 2 & 68 & 68,67 & 68,33 & \\
\hline
\end{tabular}

Tabel 6. Rekapitulasi Hasil Tes formatif pada Siklus I

\begin{tabular}{|c|c|c|}
\hline No & Uraian & Hasil Siklus I \\
\hline 1 & Nilai rata-rata tes formatif & 68,33 \\
\hline 2 & Jumlah peserta didik yang tuntas belajar & 18 \\
\hline 3 & Persentase ketuntasan belajar & $60 \%$ \\
\hline
\end{tabular}

Untuk lebih jelasnya dapat dilihat pada gambar grafik dibawah ini :

\section{Grafik 1 Hasil Tes Formatif Siklus I}

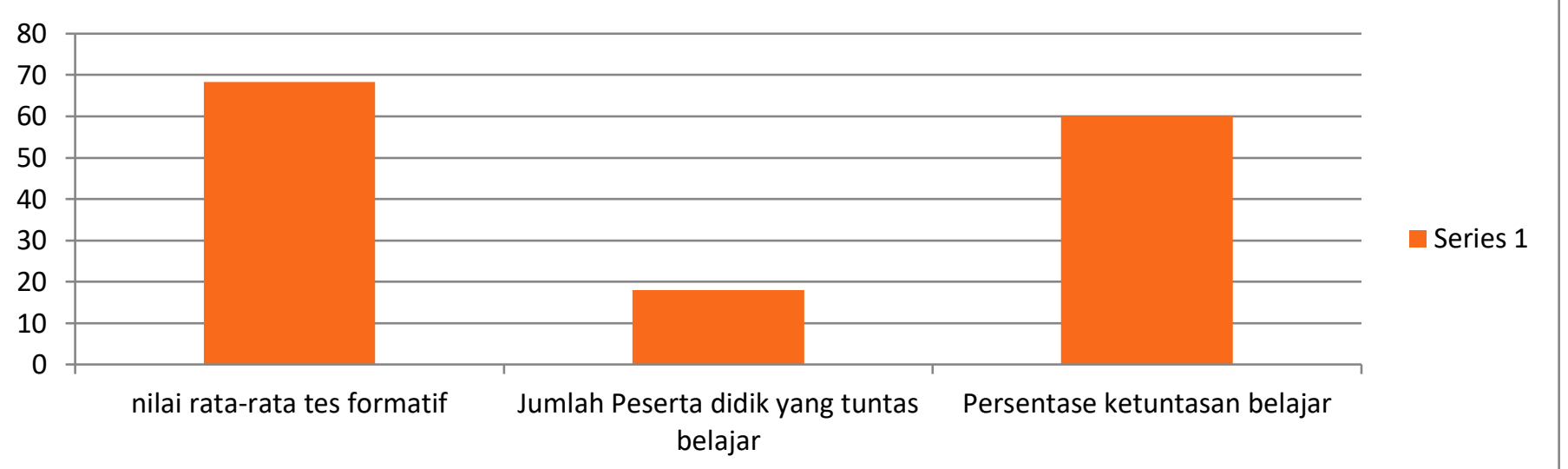

\section{Grafik 1. Hasil Tes Formatif Siklus 1}

Berdasarkan tabel di atas dapat dijelaskan bahwa dengan menerapkan model pembelajaran kooperatif tipe think pair share diperoleh niai rata-rata hasil belajar nilai peserta didik adalah 68,33 dengan ketentuan belajar mencapai $60 \%$ (18) peserta didik dari 30 peserta didik. Hasil belajar tersebut menunjukkan bahwa pada siklus I secara klasikal peserta didik ketuntasan hasil belajanya belum mencapai indicator kercapiannya yaitu sebesar $80 \%$. Hal disebabkan karena aktivitas peserta didik dalam mengikuti kegiatan belajar mengajar di kelas belum focus dengan menggunakan model pembelajran unpan balik. Di samping itu guru juga dalam pengelolaan pembelajarannya belum maksimal dikarenakan masih banyak kekuarangan-kekurangan , untuk lebih jelasnya dapat dilihat tabel 7 hasil observasi pengelolaan pembelajaran pada siklus I. Hasil penelitian di atas sejalan dengan pendapat Nana Sudjana (2009:22) yang mengemukakan hasil belajar adalah kemampuan-kemampuan yang dimiliki peserta didik setelah ia menerima pengalaman belajarnya.

Hasil Observasi Pengelolaan Pembelajaran Siklus I

Tabel 7. Hasil Observasi Pengelolaan Pembelajaran Siklus I

\begin{tabular}{llcc}
\hline No & \multicolumn{1}{c}{ Aspek yang diamati } & Penilaian & Rata-rata \\
\hline 1 & Pengamatan KBM & & \\
A. Pendahuluan & & \\
1. Guru mempersiapkan RPP & 4 & 4 \\
2. Guru menjelaskan tujuan pembelajran & 3 & 4 \\
3. Guru memotivasi siswa & 3 & 4 \\
4. Guru menjelaskan KD dan Indiaktor yang harus dicapai oleh peserta didik & 3 & 3 \\
B. Kegiatan inti & 3,5 & 3 \\
1. Guru membuat kelompok siswa menjadi 5 kelompok & 2 & 2
\end{tabular}


2. Guru membagikan lembaran materi pada semua kelompok dengan jumlah pada semua kelompok 10 buah

3. Guru mengajukan pertanyaan lisan dan tulisan pada setiap kelompok

4. Guru mengamati kerja dan minat siswa dalam mengerjakan tugas

C. Penutup
1. Guru selalu mengajak siswa untuk menyimpulkan pembelajaran pada akhir kegiatan
2. Guru melakukan penilaian secara individual dan kelompok
3. Guru merefleksi materi pembelajaran bersama siswa
4. Guru memberi tugas di rumah JUMLAH

Berdasarkan tabel 7 hasil pengamatan kegiatan belajar mengajar di atas diperoleh informasi aspekaspek yang perlu diperbaiki adalah Mengatur peserta didik dlam kelompok-kelompok belajar, membimbing peserta didik melakukan kegiatan pembelejaran model unpan balik. merupakan kelemahan yang terjadi pada siklus 1, akan menjadi bahan kajian pada refleksi dan revisi yang akan dilakukan pada siklus II. Hasil observasi pengeolaan pembelajran pada siklus I baru mencapai nilai skor 33,5 (69,79\%). Dengan demikian hasil tersebut indicator ketercapainya belum berhasil seuai dengan indikatornya adalah mencapai nilai $80 \%$.

\section{Hasil Observasi Aktivitas Peserta Didik}

Tabel 8. Hasil Observasi Rata-Rata Aktivitas Peserta Didik Siklus I

\begin{tabular}{clcccc}
\hline No & Aktivitas Peserta didik yang diamati & Nilai P1 & Nilai P2 & Nilai rata-rata & Persetase \\
\hline 1 & Mendengarkan penjelasan guru & 2,37 & 2,53 & 2,45 & 61,25 \\
2 & Siswa menjawab pertanyaan & 2,13 & 2,47 & 2,30 & 57,5 \\
3 & Siswa mengerjakan tugas yang diberikan guru & 2,30 & 2,77 & 2,54 & 63,50 \\
4 & Siswa mendiskusikan hasil kerja kelompok & 2,30 & 2,47 & 2,39 & 59,75 \\
5 & Siswa menyimpulkan hasil diskusi kelompok & 2,33 & 2,47 & 2,40 & 60,00 \\
\hline
\end{tabular}

Hasil penelitian pada observasi diatas sejalan dengan pendapat (Nanang hanafiah, 2010:23) yang mengemukakan belajar sangat membutuhkan adanya aktivitas, dikarenakan tanpa adanya aktivitas proses belajar tidak mungkin berlangsung dengan baik. Berdasarkan hasil analisis data aktivitas siswa menunjukkan dari 5 aspek yang diamati yang perlu diperbaiki oleh siswa adalah kelima aspek tersebut. Kelima aspek tersebut adalah Mendengarkan dan memperhatikan penjelasan guru $(2,45)=61,25 \%$, aspek siswa menjawab pertanyaan $(2,30)=56,5 \%$ (cukup), aspek siswa mengerjakan tugas yang diberikan guru
$(2,54)=63,50 \%$ (cukup) , aspek siswa mendiskusikan hasil kerja kelompok $(2,39)=59,75 \%$ (cukup) dan aspek siswa menyimpulkan hasil diskusi kelompok $(2,40)=$ $60,00 \%$ (cukup). Berdasarkan dari skor rata-rata dua kali pertemuan untuk aktivitas siswa baru mencapai $2,42=60,50 \%$ (cukup) untuk siklus I. Maka dengan demikian perlu dilanjutkan ke siklus II agar perlu adanya peningkatan hasil aktivitas siswa.

\section{Siklus II}

Hasil Tes Peserta Didik

Tabel 9. Hasil Tes Formatif Peserta Didik Siklus II

\begin{tabular}{|c|c|c|c|c|c|}
\hline No. & Nama & Nilai UH 1 & Nilai UH 2 & Rata-Rata & Kriteria \\
\hline 1 & Adelio Noor Alvaro & 90 & 90 & 80 & Tuntas \\
\hline 2 & Ananda Saputra & 80 & 85 & 82.5 & Tuntas \\
\hline 3 & Cherlly Ayu Cantika Putri & 90 & 90 & 90 & Tuntas \\
\hline 4 & Dafa Aprilliandy & 80 & 85 & 82.5 & Tuntas \\
\hline 5 & Deby Chintya Bella & 90 & 90 & 90 & Tuntas \\
\hline 6 & Dzakiyah Rafifah Artanti & 80 & 80 & 80 & Tuntas \\
\hline 7 & Gania Aura Darningsih & 75 & 75 & 75 & Tuntas \\
\hline 8 & Gavrila Pratama Ivander S & 80 & 80 & 80 & Tuntas \\
\hline 9 & Gita Amelia Putri & 70 & 80 & 55 & Tuntas \\
\hline 10 & Iqbal Mediawan & 80 & 80 & 80 & Tuntas \\
\hline 11 & Julius Manulang & 70 & 70 & 70 & Tidak Tuntas \\
\hline 12 & Kalila Azzahra Putri Nasution & 60 & 60 & 60 & Tidak Tuntas \\
\hline 13 & Muhammad Fadhil Rizqi & 80 & 80 & 80 & Tuntas \\
\hline 14 & Meyza Syarif & 75 & 75 & 75 & Tuntas \\
\hline 15 & Aupa Dzakia Fahmi & 90 & 90 & 90 & Tuntas \\
\hline 16 & Muhammad Fikri Alfalah & 90 & 90 & 90 & Tuntas \\
\hline 17 & Muhammad Haikal & 90 & 90 & 90 & Tuntas \\
\hline 18 & Muhammad Novriyansyah & 90 & 90 & 90 & Tuntas \\
\hline 19 & Muhammad Revan Ferdinansya & 90 & 95 & 92,5 & Tuntas \\
\hline 20 & Nadia Balqis Adila & 90 & 90 & 90 & Tuntas \\
\hline 21 & Narendra Gayuh Rajasa & 70 & 70 & 70 & Tidak Tuntas \\
\hline 22 & Natasia Novianti Siahaan & 85 & 80 & 80 & Tuntas \\
\hline 23 & Nazila Winastia & 80 & 80 & 80 & Tuntas \\
\hline 24 & Oktafianus Viter Samosir & 80 & 90 & 85 & Tuntas \\
\hline 25 & Quinsha Nabila Vadisha & 75 & 75 & 75 & Tuntas \\
\hline 26 & Ramot Samuel Mangapoi Hutas & 70 & 70 & 70 & Tuntas \\
\hline 27 & Rivaldo & 85 & 85 & 85 & Tuntas \\
\hline 28 & Rizki Naufal Nadhif & 80 & 80 & 80 & Tuntas \\
\hline 29 & Rohana Enjelika Rumabutar & 75 & 75 & 75 & Tuntas \\
\hline 30 & Rosa Paulina & 65 & 60 & 62,5 & Tidak Tuntas \\
\hline
\end{tabular}


Jumlah

rata-rata nilai $\mathrm{UH} 1$ dan 2
2415

80,5
2439

81,30
2422,5

80,75

Tabel 10. Rekapitulasi Hasil Tes Formatif pada Siklus II

\begin{tabular}{|c|c|c|}
\hline No & Uraian & Hasil Siklus I \\
\hline 1 & Nilai rata-rata tes formatif & 80,75 \\
\hline 2 & Jumlah peserta didik yang tuntas belajar & 25 \\
\hline 3 & Persentase ketuntasan belajar & $83,33 \%$ \\
\hline
\end{tabular}

Untuk lebih jelasnya dapat dilihat pada gambar grafik dibawah ini :

\section{Grafik 2 Hasil Tes Formatif Siklus II}

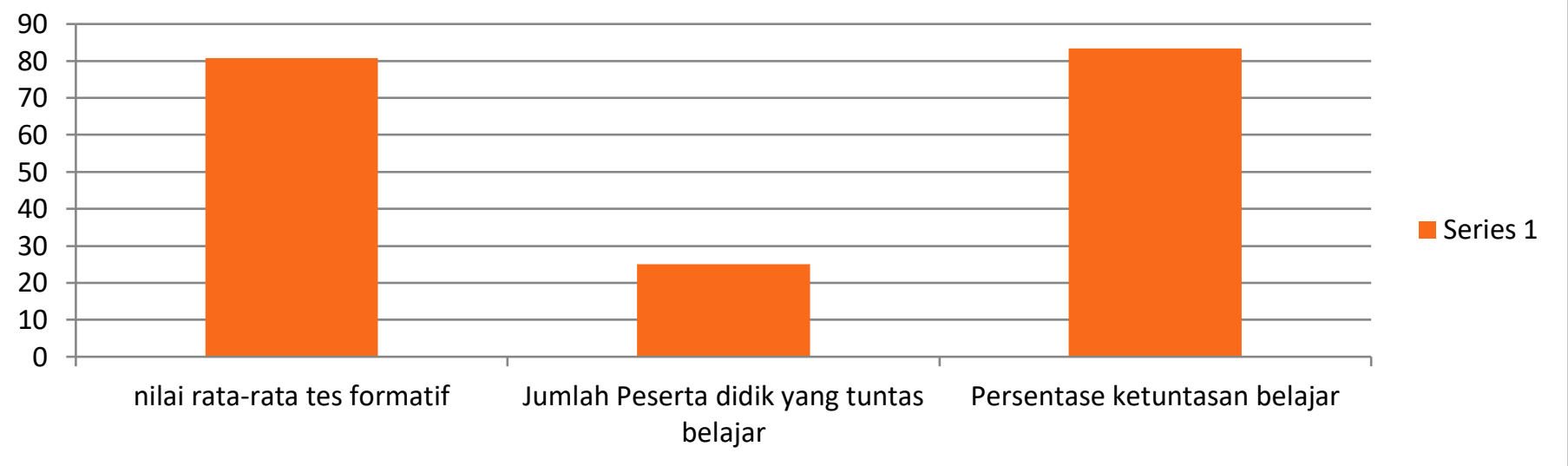

Grafik 2. Hasil Tes Formatif Siklus II

Berdasarkan tabel di atas dapat dijelaskan bahwa dengan menerapkan model pembelajaran kooperatif tipe think pair share diperoleh niai rata-rata hasil belajar nilai peserta didik adalah 80,75 dengan ketentuan belajar mencapai 83,33 \% (25) peserta didik dari 30 peserta didik. Hasil belajar tersebut menunjukkan bahwa pada siklus I secara klasikal peserta didik ketuntasan hasil belajanya belum mencapai indikator kecapainnya yaitu sebesar $80 \%$. Hal disebabkan karena aktivitas peserta didik dalam mengikuti kegiatan belajar mengajar di kelas belum fokus dengan menggunakan model pembelajran umpan balik . Di samping itu guru juga dalam pengelolaan pembelajrannya belum maksimal dikarenakan masih banyak kekuarangan-kekurngan , untuk lebih jelasnya dapat dilihat tabel 11 hasil observasi pengelolaan pembelajaran pada siklus II. Hasil penelitian di atas sejalan dengan pendapat Nana Sudjana (2009:22) yang mengemukakan hasil belajar adalah kemampuan-kemampuan yang dimiliki peserta didik setelah ia menerima pengalaman belajarnya.

Hasil Observasi Pengelolaan Pembelajaran Siklus II

Tabel 11. Hasil Observasi Pengelolaan Pembelajaran Siklus II

\begin{tabular}{|c|c|c|c|c|}
\hline \multirow{2}{*}{ No } & \multirow{2}{*}{ Aspek yang diamati } & \multicolumn{2}{|c|}{ Penilaian } & \multirow[t]{2}{*}{ Rata-rata } \\
\hline & & P1 & $\mathrm{P} 2$ & \\
\hline \multirow[t]{16}{*}{1} & $\begin{array}{l}\text { Pengamatan KBM } \\
\text { A. Pendahuluan }\end{array}$ & & & \\
\hline & 1. Guru mempersiapkan RPP & 4 & 4 & 4 \\
\hline & 2. Guru menjelaskan tujuan pembelajran & 4 & 4 & 4 \\
\hline & 3. Guru memotivasi siswa & 4 & 4 & 4 \\
\hline & 4. Guru menjelaskan KD dan Indiaktor yang harus dicapai oleh peserta didik & 4 & 4 & 4 \\
\hline & B. Kegiatan inti & & & \\
\hline & 1. Guru membuat kelompok siswa menjadi 5 kelompok & 3 & 3 & 3 \\
\hline & $\begin{array}{l}\text { 2. Guru membagikan lembaran materi pada semua kelompok dengan jumlah pada } \\
\text { semua kelompok } 10 \text { buah }\end{array}$ & 4 & 4 & 4 \\
\hline & 3. Guru mengajukan pertanyaan lisan dan tulisan pada setiap kelompok & 3 & 4 & 3,5 \\
\hline & 4. Guru mengamati kerja dan minat siswa dalam mengerjakan tugas & 2 & 3 & 2,5 \\
\hline & C. Penutup & & & \\
\hline & 1. Guru selalu mengajak siswa untuk menyimpulkan pembelajaran pada akhir kegiatan & 4 & 4 & 4 \\
\hline & 2. Guru melakukan penilaian secara individual dan kelompok & 3 & 4 & 3,5 \\
\hline & 3. Guru merefleksi materi pembelajaran bersama siswa & 3 & 3 & 3 \\
\hline & 4. Guru memberi tugas di rumah & 4 & 4 & 4 \\
\hline & JUMLAH & 42 & 45 & 43,5 \\
\hline
\end{tabular}

Berdasarkan tabel 11 hasil pengamatan kegiatan belajar mengajar di atas diperoleh informasi aspekaspek yang perlu diperbaiki adalah Mengatur peserta didik dlam kelompok-kelompok belajar, membimbing peserta didik melakukan kegiatan pembelejaran model unpan balik. merupakan kelemahan yang terjadi pada siklus 1, akan menjadi bahan kajian pada refleksi dan revisi yang akan dilakukan pada siklus II. Hasil observasi 
pengeolaan pembelairan pada siklus II sudah mecapai indiaktor keberhasilannya sudah mellebih dari $80 \%$ yaitu dengan skor nilai 43,5 atau $90,63 \%$.

\section{Hasil Observasi Aktivitas Peserta Didik}

Tabel 12. Hasil Observasi Rata-Rata Aktivitas Peserta Didik Siklus II

\begin{tabular}{|c|c|c|c|c|c|}
\hline No & Aktivitas Peserta didik yang diamati & Nilai P1 & Nilai P2 & Nilai rata-rata & Persetase \\
\hline 1 & Mendengarkan penjelasan guru & 3,50 & 3,67 & 3,59 & 89,75 \\
\hline 2 & Siswa menjawab pertanyaan & 3,30 & 3,77 & 3,54 & 88,5 \\
\hline 3 & Siswa mengerjakan tugas yang diberikan guru & 3,53 & 3,57 & 3,55 & 88,75 \\
\hline 4 & Siswa mendiskusikan hasil kerja kelompok & 3,37 & 3,50 & 3,44 & 86,00 \\
\hline 5 & Siswa menyimpulkan hasil diskusi kelompok & 3,47 & 3,67 & 3,57 & 89,25 \\
\hline
\end{tabular}

Hasil penelitian pada observasi diatas sejalan dengan pendapat (Nanang hanafiah, 2010:23) yang mengemukakan belajar sangat membutuhkan adanya aktivitas, dikarenakan tanpa adanya aktivitas proses belajar tidak mungkin berlangsung dengan baik. Berdasarkan hasil analisis data aktivitas siswa menunjukkan dari 5 aspek yang diamati yang perlu diperbaiki oleh siswa adalah kelima aspek tersebut. Kelima aspek tersebut adalah Mendengarkan dan memperhatikan penjelasan guru $(3,59)=89,75 \%$, aspek siswa menjawab pertanyaan $(3,54)=88,5 \%$ (sangat baik), aspek siswa mengerjakan tugas yang diberikan guru $(3,55)=88,75 \%$ (sangat baik), aspek siswa mendiskusikan hasil kerja kelompok $(3,44)=$ $86,00 \%$ (baik) dan aspek siswa menyimpulkan hasil diskusi kelompok $(3,57)=89,25 \%$ (sangat baik). Berdasarkan dari skor rata-rata dua kali pertemuan untuk aktivitas siswa baru mencapai 3,54=60,50\% (sangat baik) untuk siklus II. Maka dengan demikian perlu dilanjutkan menunjukkan bahwa hasil pada siklus II sudah melebihi dari $80 \%$ untuk aktivitas siswa maka PTK ini hanya dilakaukan pada siklusll untuk dua kali pertemuan.

\section{Pembahasan}

\section{Ketentuan hasil belajar peserta didik}

Dari hasil penelitian ini menunjukan bahwa pembelajaran dengan model pembelajaran mtode unpan balik memiliki dampak positif dalam meningkatkan hasil belajar peserta didik dari siklus I sampai siklus II, untuk lebih jelasnya dapat dilihat dibawah ini:

Tabel 13. Perkembangan Hasil Belajar Peserta Didik

\begin{tabular}{cccc} 
& Nilai rata-rata & \multicolumn{2}{c}{ Ketuntasan } \\
& & Jumlah & Persen \\
\hline Pra siklus & 59,50 & 12 & $40 \%$ \\
Siklus I & 68,33 & 18 & $60 \%$ \\
Siklus II & 80,75 & 25 & $83,33 \%$ \\
\hline
\end{tabular}

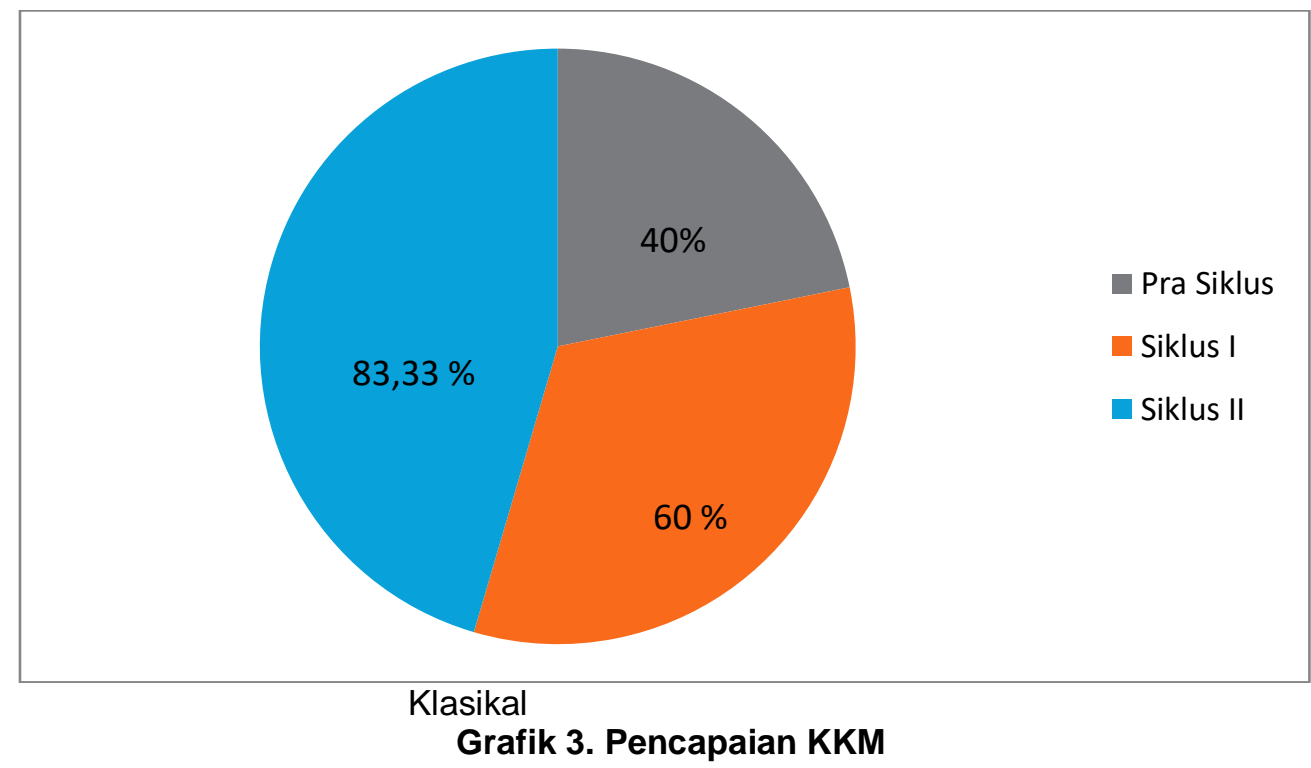

\section{Kemampuan Guru dalam Mengelola Pembelajaran}

Guru telah mampu menerapkan langkah model pembelajaran unpan balik dengan baik, sejak membentuk kelompok belajar sampai dengan memanage waktu pembelajaran dengan baik sehingga target pembelajaran dapat tercapai. Adapu langkahlangkah pembelajaran yang dugunakan adalah sesuai dengan model pembelajaran unpan balik sesuai yang dilakaukan pada penelitian siklus I dan II.

\begin{tabular}{|c|c|c|c|c|}
\hline No. & $\begin{array}{c}\text { Skor } \\
\text { Total } \\
\text { Siklus I }\end{array}$ & Persentase I & $\begin{array}{c}\text { Skor Total } \\
\text { Siklus II }\end{array}$ & $\begin{array}{c}\text { Persentase } \\
\text { Siklus II }\end{array}$ \\
\hline 1 & 33,5 & 69,79 & 43,50 & $90,63 \%$ \\
\hline
\end{tabular}




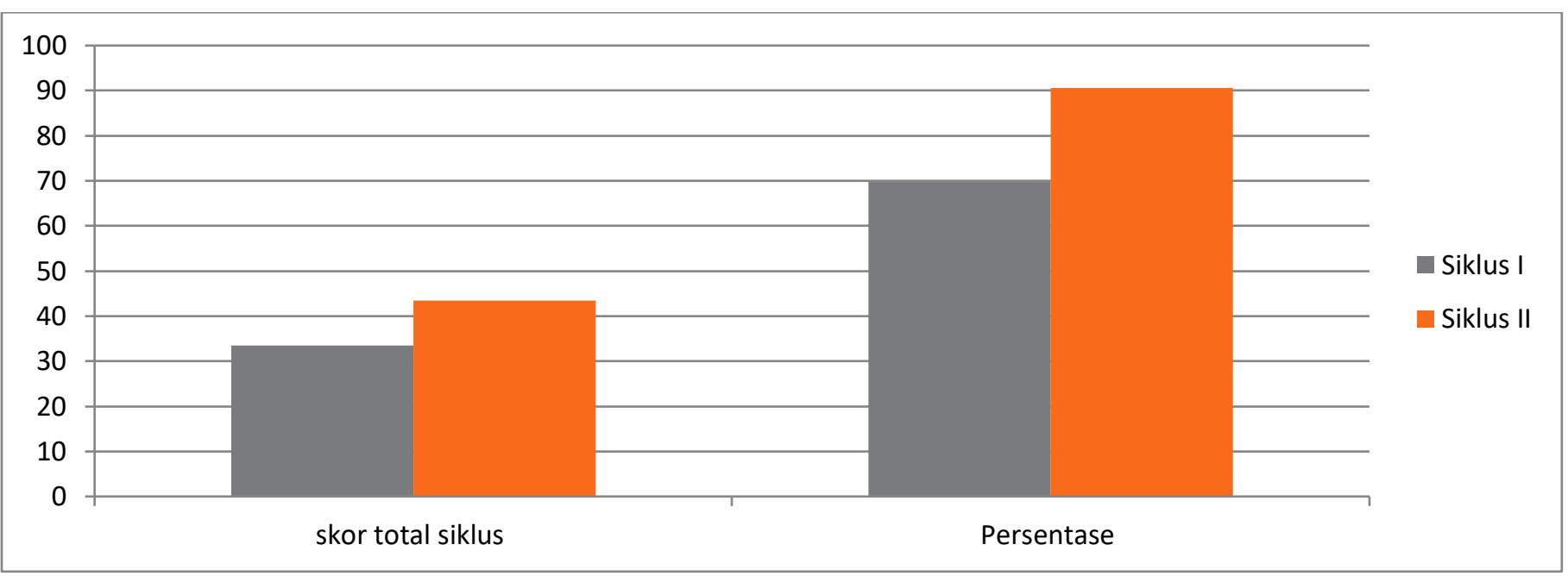

Grafik 4 Rekapitulasi Hasil Observasi Pengelolaan Pembelajaran Guru

\section{Hasil Observasi Aktivitas Peserta Didik dalam Pembelajaran}

Berdasarkan hasil pengamatan observasi di atas dari siklus I sampai siklus II dapat disimpulkan bahwa berdasarkan hasil oservasi aktivitas peserta didik dalam pembelajaran dapat ditingkatkan melalui metode umpan balik. Hasil penelitian pada observasi diatas sejalan dengan pendapat (Nanang hanafiah, 2010:23) yang mengemukakan belajar sangat membutuhkan adanya aktivitas, dikarenakan tanpa adanya aktivitas proses belajar tidak mungkin berlangsung dengan baik. Berdasarkan dari Kajian teori yang dikemukakan bahwa model pembelajaran Metode Umpan Balik adalah pemberian informasi yang diperoleh dari tes atau alat ukur lainnya kepada siswa untuk memperbaiki atau meningkatkan pencapaian atau hasil belajar Siswa menerima umpan balik dari guru dalam bentuk lisan maupun tulisan. Umpan balik verbal umumnya diberikan pada sesi tanya jawab. Sedangkan salah satu umpan balik tertulis yang paling umum diberikan adalah nilainilai dalam penilaian formal, seperti ujian tertulis dengan menggunakan kertas dan pensil.

\section{SIMPULAN}

Dari hasil kegiatan pembelajaran yang telah dilakukan selama dua siklus, dan berdasarkan seluruh pembahasan serta analisi yang telah dilakukan dapat disimpulkan bahwa pembelajaran dengan metode umpan balik memiliki dampak positif dalam meningkatkan aktivitas siswa dan hasil belajar IImu Pengetahuan Alam (IPA) peserta didik kelas IV B SD Negeri 64/ IV Kota Jambi, terlihat pada setiap siklusnya yaitu pra siklus $(59,50 \%)$ siklus I (68,33\%) siklus II $(80,75 \%)$.

Peningkatan hasil belajar IImu Pengetahuan Alam (IPA) melalui model pembelajaran umpan balik didukung oleh peningkatan aktivitas belajar peserta didik, serta dari hasil wawancara yang dilakukan pada peserta didik menyatakan bahwa peserta didik lebih termotivasi dalam belajar dengan menggunakan model ini karena suasana pembelajaran menjadi lebih menyenangkan sehingga materi yang diberikan mudah dipahami oleh peserta didik.
Selanjutnya untuk peningatan keaktifan siswa mengalami peningktan yaitu pada siklus I dengan nilai rata=rata untuk pertemuan 1 dan 2 menunjukkan hasil pada siklus I yaitu 2,54 dan siklus II mengalami peningkatan yaitu 3,64 (91\%). Selanjutnya untuk presentase ketuntasan hasil belajar mengalamai peningkatan yaitu untuk siklus pra siklusi yang tuntas hanya 12 siswa (40\%), siklus I 18 siswa (60\%) dan siklus II menjadi 25 orang yang tuntas $(83,33)$.

\section{DAFTAR PUSTAKA}

Ade Rukmana dan Asep Suryana. 2006. Pengelolaan kelas. Bandung. UPI Press

Arikunto, Suharsimi. 1990. Dasar-Dasar Evaluasi Pendidikan. Jakarta : Bumi Aksara

Bahri Syaiful dan Zain Aswan. 2006. Strategi Belajar Mengajar. Jakarta: PT. Rineka Cipta.

Depdiknas .2006. Permendiknas No 22 Tahun 2006 Tentang Standar Isi. Jakarta : Depdiknas.

Dr., Evaluasi Hasil Belajar dan Umpan Balik, PT Grassindo anggota IKAPI Jakarta : 1991.

E.Mulyasa, Praktek Penelitian Tindakan Kelas. cet.II : Bandung :PT Remaja Rosdakarya, 2009

Gagne dan Berliner. 1984. Teori Belajar Behavioristik dan Penerapannya dalam Pembelajaran.

Hamalik, Oemar. Proses Belajar Mengajar, Jakarta, Bumi Aksara, 2001 hal 36

Harlen. W. Primary science taking the Plunge, London, HEB Itd, alih bahasa oleh Muhammad Khofifi, Tehnik-tehnik Mendapatkan Umpan Balik. 1987 hal $9-12$

Mujdiono, Proses Belajar Mengajar, PT. Remaja Rosdakarya Bandung, 2000.

Mursell \& Nasution,.Mengajar dengan Sukses. Jakarta: Sinar Grafika Offset. 2002.

Nana Sudjana, Penilaian Hasil Proses Belajar Mengajar, PT. Remaja Rosdakarya, 2004, hal. 22.

Nana Sudjana,. Tehnologi Pengajaran. PT Sinar Baru. Bandung. 1989.

UU Republik Indonesia Nomor 20 Tahun 2003 tentang Sistem Pendidikan Nasional. Jakarta: Departemen Pendidikan Nasional. , 2003. 